\title{
Author, landscape and communication in Estonian haiku
}

\author{
Kati Lindström \\ Department of Semiotics, University of Tartu \\ Tiigi St. 78, 50410 Tartu, Estonia \\ e-mail: klndstrm@yahoo.com
}

\begin{abstract}
Present article tries to give insight into the ways in which Estonian haiku models its author and communicates with the reader. The author thinks that while Japanese haiku is a predominantly autocommunicative piece of literature, where even a fixed point of view is not recommended, Estonian literary conventions are oriented towards openly communicational texts, which convey a fixed axiology and rely on abundant use of pronouns and rhetorical questions, addresses and apostrophes. While there is a considerable amount of Estonian haiku that depend on Estonian literary conventions, most of the Estonian haiku texts, however, are oriented to the Japanese model. These texts have been labelled "the catalogues of landscape", as they are constituted by naming different landscape objects without developing a line of narration. Thereby every landscape element in poetry is granted its own voice, and through this multitude of voices inside the text, the reader is forced to enter an autocommunicative process of remodelling him/herself.
\end{abstract}

\section{The problem of communication in poetry}

Every piece of poetry can be considered an act of communication by virtue of being written and read by someone, either another person or the same person at a different instant of time. Therefore functioning of a poetic work can be depicted according to the communication schema proposed by Roman Jakobson in his famous "Closing statement: Linguistics and poetics" (1966), where a poem is a message sent by the author to the reader. The message (poem) presupposes a context, seizable to addressee, a code (poetic language) and a contact, "a 
physical channel and psychological connection between the addresser and the addressee" (Jakobson 1966: 353). Each of these elements is connected with one of the basic functions of language.

As Juri Lotman has eloquently proved in a number of his writings, this schema of communication applies to a very limited number of texts in any given culture, and is certainly inadequate in describing artistic texts (e.g., first section of Y. Lotman 1990a). Although Roman Jakobson himself was very far from a simplistic view of the matters and asserts that all the six language functions are represented in every single text, including works of literature, still the very fact that his analyses of literary texts foreground the element of message itself (i.e. the poetic function), brings us to the question about the role played by other elements of an act of communication in a poetic text.

From this point of view there surges the rich scholarship on the problem of author in literature, the relation of author with reader's interpretation, and the process of reading (e.g. Rezeptionsästhetik). As a rule, these writings complicate the issue of text's outer communication even further, introducing the notions of "model reader" and "model author". "Model reader" signifies a model of a possible reader foreseen by the author of the text, according to which the author chooses the code and other textual elements (Eco 1984: 7), the text's orientation towards a certain type of memory (Y. Lotman 1990a: 64). "Model author" is an authorial image constructed by the reader according to the textual hints carried by the text. The author becomes "a textual strategy establishing semantic correlations and activating the Model Reader" (Eco 1984: 11); author is a function, "the principle of unity of writing" both at the level of stylistics and world view (Foucault 1989: 204). Also Yuri Levin, whose view of communication in lyric poetry will partly be taken as a point of departure in further discussion, differentiates between three levels of communication in poetry: the real and the implicit reader/author, and the internal communication (Levin 1973).

These theories have sought to overcome the disadvantages of the classical model of communication by splitting text into several categories and layers, whereas the real author has been either dismissed altogether from the discussion or has been treated as a more or less coherent sender of a poetic message, which then later diversifies by itself, building multifarious images of reader and writer.

For Juri Lotman, communication is a fundamentally different phenomenon, because neither the text nor the other participants of the act of communication precede it: "they become such only in course of 
this act" (M. Lotman 2001: 102). What is most important here, is that not only the text is not identical with itself, but also the addresser and addressee are split into several personalities and an act of communication can be directed from a person to him/herself. In an act of autocommunication the carrier of information remains the same, but a secondary code is introduced into the message, thereby changing the information content of the message, "and this leads to a restructuring of the actual 'I' itself' (Y. Lotman 1990a: 22) As Juri Lotman puts it,

My ego may be regarded as a semiosphere. It represents a collection of addressees. When I address myself I am addressing one of these addressees and I identify myself with him. [...] I identify with my multifaceted personality, with my polysemiotic personality, with some single language, with one addressee, and in this manner my own self has undergone a transformation. (Lotman, Broms 1988: 120-121)

For Lotman every text comprises both the elements of 'I' to 's/he' and 'I' to 'I' communication, although one of the systems is usually dominant. In a poetic text the autocommunicative elements are prevalent already by virtue of metre and rhythm, which force the reader to take a poem as a code and not as an informative text (Y. Lotman 1990a: 2934). Yuri Levin asserts similarly that heightened autocommunicative functioning is inherent to poetry because as poetry is usually built in monologic form, it can be regarded as author's dialogue with him/ herself (Levin 1973: 177-178). He also thinks that autocommunicativity is also projected into the act of reception, where a text becomes a reader's dialogue with him/herself (Levin 1973).

Evidently, the complexity of communicational activity surrounding a piece of poetry as it is described above will leave its trace to the communicational relations inside the text. If we are to agree that "an artistic model in its most general form recreates the image of the world, i.e. it models the relations of the person and world for a given consciousness" (Y. Lotman 1990b: 159), and if we consider the "author" as a principle of unity or a subject for a given artistic model, we have to admit that the way how author and communicational patterns are represented in a text is one of the most important textual strategies altogether. At that, we have to remember that in a literary text "the readership image and its attendant pragmatic aspects do not automatically determine the type of text, but become elements of a free artistic game and consequently acquire supplementary significance" (Y. Lotman 1990a: 64). 


\section{Haiku in Japan and Estonia — texts and specifics}

Before continuing with the analysis of concrete texts, it is important to mention the nature and specifics of haiku poetry ${ }^{1}$ in Japan and Estonia, and to give a short account of the texts analysed.

Haiku poetry in Japan came to be considered an elevated form of art only with the poetry of Matsuo Bashō (1644-1694). Before that it was mostly considered a little frivolous amusement, which was most often composed in groups as a collective pastime. Bashō, who was deified within hundred years after his death, laid the grounds and requirements of the haiku form, which remained unquestioned until Meiji Restoration (1868-1912), a time of extensive European influence in Japan. As it is neither possible nor relevant to cover the whole haiku history and all the aspects of the form, the following analysis will limit itself only to the remarks about the haiku of Matsuo Bashō, and only to those aspects directly connected with their communicational functioning.

Haiku started to be written in Estonia in 1960ies, and although the artistic quality and the importance of the form have declined over the years, it is still very much a living poetic form. It is complicated to map the exact process of adoption of the form for multifarious reasons, but more or less we can say that for an average Estonian haiku writer haiku means a poem about nature with 17 syllables split into three lines. ${ }^{2}$ The Estonian haiku texts analysed in the present article are taken from all the authorial collections of poetry published after the WW II in Estonia until the year 2001. Altogether it is 1455 texts by 97 authors from 127 collections of poetry.

The stand of poetry in classical Japanese culture and in post-war Estonia has some crucial differences.

In classical Japanese culture, poetry was not a meagre object of aesthetic pleasure, but it became socially institutionalised. This applies first and foremost to earlier waka poetry, composing which was an

1 Term 'haiku' can cause some confusion as it was adopted only by the reformer of haiku literature, Masaoka Shiki, in the end of $19^{\text {th }}$ century to designate an independent verse of 17 morae, which was not meant to start a renga sequence. Earlier both these and the first verses of longer renga sequences had been called 'hokku' or 'starting verse'. In the present article I use the term 'haiku' for independent verses both before and after Shiki. Apart from the mora-count haiku has many other requirements, only a few of which will be discussed later.

${ }^{2}$ For a general description of Estonian haiku, its importance in Estonian literary context and the most important patterns of adoption see Lindström 2001. 
obligatory skill for every Japanese courtier, but also haiku poetry had its social functions. Developed initially from the first verse of a renga sequence it had to contain a greeting to the host of the sequence, ${ }^{3}$ and the host replied with a second verse, expressing his gratitude on visit. A poet, visiting somebody, presented the host with haiku, even if no renga sequence followed. Collective haiku composing was common at instances of moon-viewing or when appreciating cherry blossoms, but also haiku competitions were held, where people composed haiku at the spot on a given topic. While some authors consider this social function irrelevant to a poem's analysis, because Bashō often remade his greeting poems or presented the same haiku to several different hosts (Kawamoto 2000: 49-51), the others think that the "greeting spirit" is essential to understanding haiku. A haiku can greet not only humans, but it can be composed to greet a famous place, known from earlier poetry (Shirane 1998).

It would be simplistic to think that such communicative functioning has no impact to a poem's structure, and in fact, as it is shown by Horikiri Minoru, communicative textual elements in classical Japanese poetry (including waka) are more frequent during the periods when social poetic interaction was tighter (Horikiri Minoru 2002: 129-130). Moreover, he considers haiku (esp. Bashō's haiku) an especially communicative form of poetry, because the ratio of haiku containing communicative expressions ${ }^{4}$ is relatively high compared to waka (16.8\%) (Horikiri Minoru 2002). Half of the texts among this $16.8 \%$ are written either as greetings or are a part of a longer piece of haiku prose (haibun).

Evidently, this is not the way poetic interaction is organised in Western poetic context, which departs from Romanticist assumption that a poetic genius cannot possibly create a masterpiece on demand. Although we can probably imagine some congress among the circles of amateur poets, who are also ardent haiku writers, it is safe to say that this kind of social functioning is alien to Estonian haiku. Parado-

${ }^{3}$ A renga sequence consisted of 36,60 or 100 verses and was composed by two, three or more authors, who took turns in composing alternative verses of 5-75 and 7-7 mora. Classical renga had extremely complex rules as to how the preceding verse can be capped, the most important of which forbids the development of one and the same lyrical topic through more than three consecutive verses.

4 'Communicative expressions' is an inaccurate equivalent for ' $y \bar{o} k y \bar{u}$ hyōgen 要求表現', which comprises expressions of imperative, prohibition, volition (esp. $m u$, mogana) and rhetorical questions. 
xically enough, as we see later, it is the Estonian poetry, which tends to use more communicative expressions: among the 275 poems listed in a collection of Estonian nature poems "Eesti looduslüürikat" (Vaarandi 1980), there are only 235 (85.5\%), which use communicative elements. ${ }^{5}$ Among Estonian haiku, which draw simultaneously from Japanese and Estonian conventions, there are 555 texts (38\%), which are openly communicational.

Key to the issue lies probably in the way both literary traditions see author.

Estonian literary tradition and its clichés surge from the Neoromanticist poetry in the beginning of the 20th century. Such literature, as the romanticist literature proper and modern European literature until postmodernism in general, takes the author as a centre of axiology. The truth of the author coincides with the truth of the text, while the text itself is presented to the reader as ready-made, i.e. with relatively clear implications, topics and values. Such an author needs to be abundantly expressed through pronouns, rhetorical questions, exclamations and addresses etc to ensure that the reader will receive his/her unique message.

For Japanese literature, despite of, or rather, because of its communal character, the author's intention is not the primary category. Japanese literature can be regarded as code-oriented literature rather than text-oriented, which means that "code becomes one of the most important levels of interpretation of a poetic text, and a background mechanism that directs the creation of new poetic images" (Raud 1994: 18). The range of objects and situations that are appropriate for use in a poem at a certain occasion are catalogued and endowed with poetic essence (hon'i), which the interpretation and value of the poem relies on. Emotions appropriate for expression belonged to code and to the poetic essence of an item as well, rather than to the poet who uttered them (Keene 1971: 49). Bashō wrote his texts not as Bashō hic et nunc, but as a Poet in the spirit of the ancients, who has a certain (prescribed) fate, tasks and characteristics (Keene 1971; Katō 1997: 154). "Model author" is always an "ideal author", and "model reader" an "ideal reader".

Individualism together with the subject-object opposition came to Japanese culture (and haiku) after the Meiji Restoration (Beichman 1986: 68-73, Karatani 1993). At that, if the author does not have an

${ }^{5}$ Exact subtypes of what is called a communicative element here will be discussed in further sections. 
individual character, which could be treated as a single coherent whole, i.e. as a subject, s/he does not have an individual truth to be expressed with individual means either ${ }^{6}$. The nexus of truth is located outside both the author and the reader, which means that the reader can readily be entrusted with interpretative initiative, as the truth is not dependent on either of them. Such an author feels no particular need to manifest his/her particular individual position and the text becomes open, "validating (or at least not contradicting) the widest possible range of interpretative proposals" (Eco 1984: 33), up to the point where even a poem's real topic ('solitude', 'voidness') is up to the reader to decide (Konsihi 1999: 85-87). The whole Bashō's poetics has been subordinated to the ideal of impersonality (Ueda 1991, Keene 1971) and, as a matter of fact, the openness of those seventeen syllables can be regarded as one of the reasons why haiku literature has survived as a form of full value regardless of its brevity (Kawamoto 1993).

As discussed above, transferring textual activity from writer to reader and treating a text as a code, rather than a message, is characteristic of cultures inclined to autocommunication. Therefore we can state that the Estonian haiku author, when modelling communicational relations in text, must choose between two radically different attitudes: communicational and autocommunicational.

\section{Communicative perspectives in Estonian haiku texts}

\section{Texts with pronouns}

Pronouns are signs, which do not have a meaning in lexicon, but whose meaning is established by the very act of communication, marking the deictic zero of the utterance. Thus it is the use of pronouns, which will betray the projection of communicational force into the text first.

${ }^{6}$ It is significant that an idea of purposeful deviation from haiku's mora-count comes to the fore only with the influence of Romanticism. The unimportance of author can also be exemplified by the fact that classical Japanese literature did not know authorial collections of poetry: poems were published according to schools or gatherings, where the texts had been composed, following the order of seasons, i.e. according to the code. 
The analysis here will depart from two theories: the theory of communication in lyric poetry by Yuri Levin (1973) and the theory of communicative perspective by Mihhail Lotman (1989). Both of these authors depart from the assumption that heightened communicativity inherent to poetry is amply revealed by tendency to express every object described as an act of communication, introducing characters unmotivated by plot and addressing objects, who are incapable of communication. At that, texts, which contain no pronouns, are considered either objective or void of communication.

Yuri Levin (1973) analyses what relation the character marked by pronoun has with the author or the addressee, differentiating three different types of ' $I$ ' (personal, strange, generalising) and four types of 'you' (personal, impersonal, generalising and autocommunicative $)^{7}$. In practical terms it means the orientation of one or other character to author's or reader's position.

Mihhail Lotman (1989) takes a different approach. He asserts that every poem is reducible to a situation or an outcome of a situation. Constructing such a model meaning of a poem, he determines the function of the pronominal characters in this situation according to the theory of deep cases by Charles Fillmore. An 'I', 'we', 'you' or 's/he' or 'they' can be an agent (who causes the action), patient (on whom the action is imposed), or object (minor character in the situation). To those Fillmorean cases he adds that of a witness. A character referred to by pronoun can as well be only rhetorical or fictitious, which means that it exists only in text, but not in the situational meaning model. He derives various combinations: the character of ' $\mathrm{I}$ ' as an agent and 'you' as a patient, 'you' as an agent and 'I' as a patient, 'I' as an agent and 'he' as an object etc., and creates a rather comprehensive typology of perspectives of communication in poetry.

If we combine these theories, we can certainly achieve a rather satisfactory method for communicational analysis of a poem, the model situation of what can be constructed easily enough and at least some of the characters are designated by pronouns. Haiku texts containing pronouns are altogether $366(25 \%)$.

\footnotetext{
${ }^{7}$ Personal 'I'/'you' — when the explicit 'I' is identifiable with the author or 'our' little group, where the author belongs to, or when 'you' is identifiable with the real addressee. Generalising 'I'/'you' refers to the whole humankind or larger group. Strange 'I' - if author is not identifiable with the character designated by 'I'. Impersonal 'you' — the addressee is clearly incapable of receiving the message, e.g. is not a living being. Autocommunicative 'you' — when 'you' means 'I' (Levin 1973: 182-184).
} 
For example, in Venda Sõelsepp's haiku

Olen kui ämblik

lahkuvat suve püüdes

taban vaid sääski

I'm like a spider

Catching the leaving summer

Mosquitoes are all I get

the ' $\mathrm{I}$ ' catching the spiders is an agent of the situation. Analysing the text according to the relations between the external and the internal level of communication, we see that both the implicit and the real author can be regarded as coinciding with the ' $I$ '. This means that a reader may construct the external communication in two ways: as a confession by the author to him, or he can side himself with the author and the spider in the model situation and take the text as an act of autocommunication.

On the other hand in Eda Voll's

\author{
lubamatus unenäos \\ sajab valgust ja sina \\ matad mu lumme \\ In an impermissible dream \\ The light falls and you \\ Bury me into snow
}

we can see that the action is directed from 'you' to 'I' and thereby the communicative force is different from the verse analysed above.

While the pronouns are undoubtedly strongest in their communicational intensity when compared to other possible expressions of communicational force, there exist also different degrees of intensity among them. The intensity can be further strengthened by additional use of rhetorical questions and apostrophes in the same verse.

The strongest among the pronouns is personal 'you', especially when expressed by a verb in imperative or accompanied by a rhetorical question or address (41 out of 67 occurrences). Such a 'you' is always identifiable with the reader, and the addresser of the utterance is automatically identified with the implicit author. For example, a haiku by Ivar Ivask 


\author{
Vala veel õlut \\ õngeritvade varjus \\ liigutas koha \\ Poor some more beer \\ In the shadows of fishing rods \\ a pike perch moved
}

In this text the reader is offered an actantial position of the addressee, who is ordered to poor some more beer to the main character.

General 'you' (18 texts) has also strong communicational impact, although here the autocommunicative mechanisms start to manifest themselves more acutely, as the author is also part of that 'you' as a member of human race. On the other hand, the impersonal 'you' (29 texts) is mostly autocommunicative, as the reader can by no means place him/herself into the position of this character. Most often the 'you' in these poems is a natural object, an animal, a bird, an insect, a plant or an inanimate object of landscape, e.g. 'cloud', 'wind', 'chrysanthemum', etc.

Similar technique is common to Bashō's haiku as well. Horikiri Minoru lists addresses to fictional addressees (inanimate, supernatural or natural objects) for the sake of artistic impressiveness and as an expression of poetic madness ${ }^{8}$ as one of the five main functions of Bashō's use of communicational devices (Horikiri Minoru 2002). As the Japanese verb never indicates the grammatical category of person or number, and the use of pronouns is extremely rare, we cannot say that the instances listed by Horikiri are exactly equal to the Estonian usage of imperative or rhetorical address towards an inanimate object, which is expressed in second person. In fact, the Japanese language has a predilection to omit the subject altogether, if it is deducible from the context. On one hand this grammatical peculiarity can of course be considered a linguistic inevitability, but on the other hand every inevitability acquires secondary meaning in a poetic text. Moreover, it has even been stated that this very grammatical feature in Japanese language has certain ontological implications. For example Sakamoto Hyakudai states that "by omitting the subject, we [Japanese] try to

${ }^{8} F \bar{u} k y \bar{o}$ or poetic madness is a category in Bashō's poetics, which underlines the wish to dedicate oneself to eccentric haiku life. Kawamoto Kōji holds principally the same opinion (Kawamoto 2000: 96-97), considering all the instances of communicational elements (in my sense) to be an expression of $f \bar{u} k y \bar{o}$, and a subtype of oxymoron, which to his mind, is one of the main devices for meaning generation in haiku. 
unify subject and object", and that "the disposition which governs the Japanese sentiment is to annihilate ego, or to melt ego into the object" (1989: 1564). Be as it may linguistically, the tendency to address inanimate objects (with or without the use of pronouns) nevertheless reveals one of the main poetic principles in both Estonian and Japanese haiku, which is expressed in the communicational functioning of a poem, but also in the way tropes and figures are used: treating the natural objects as equals to the humans or diminishing the humans to the level of the smallest natural objects, to the likes of stones, grass, leaves etc. The landscape is not a background for human thoughts, but an equal living being.

That tendency is to a certain extent inherent to Estonian nature poetry in general. In the aforementioned collection of Estonian nature poetry (Vaarandi 1980), one can often meet a pattern where the authorial character or 'I' of the poem addresses nature objects or homeland either in words, thoughts or actions as if it was human, and very often this object is expressed by 'you'.

The combination of ' $\mathrm{I}$ ' and 'you' is comparable to the personal 'you' in its communicational activity, in case both pronouns are either personal or general, because in such a situation both reader and writer have been appointed fixed actantial positions in the text, and the direction of communicational force is also indicated. In most occurrences 'I' functions as the agent and 'you' as the patient of the poem, and contentwise they are mostly love poems, like the haiku by Eda Voll above. Despite the fact that confessional expression of love is alien to Japanese haiku poetry (although in earlier, pre-Bashō haiku word plays on frivolities can be found), it is still of quite a considerable frequency in Estonian haiku, encompassing also many texts with personal 'you' as agent or patient. Love haiku is common also among other Western haiku literatures, and for example the Brazilian haiku are said to combine extremely personal expressions with explicit eroticism (Lobo 1995). ${ }^{9}$

However, most of the texts using pronouns use the 1st person pronouns 'I' and 'we' (206). This is to be expected as these pronouns mark the deictic zero, which the tradition of Western lyric poetry

${ }^{9}$ Interestingly enough, Luiza Lobo proposes that this specificity of Brazilian haiku is a remnant from how the aboriginal forms of short poetry functioned: it was typical for them to be accompanied by guitar and sung out loud (Lobo 1995). This would be another example of the impact of outward communication to the inner communicational functioning of the text. 
prefers to demarcate. Even more so, because haiku in Western cultures, including Estonia, is often considered to be poetry of fresh and immediate sensation of the moment. Consider for example a quotation from the poet Jaan Kaplinski: "In haiku I expressed something, which might be called meditative experience. Some calm moment, when you are alone with your experience, your surroundings, and it all somehow resonates together: the poet, his feelings, his memories, his surroundings." 10 In his criticism of Estonian haiku Rein Raud states that "while Japanese haiku tends to depict first and foremost the echo of the inwardly in the outside [phenomena], then in Estonian haiku the tendency seems to be the opposite" (Raud 1984). It is clear, that such a cognising self, whose perception and understanding of a particular and ephemeral moment is depicted, demands special attention in the text and is bound to be indicated.

On the other hand, the effect of ' $I$ ' in poetry is ambiguous: a personal 'I' makes a text more personal, as it excludes the reader from the text, pretending to depict author's internal thoughts or his actions. Like for example in Jaan Kaplinski's

Oma südame-

lööke jään kuulatama

vihmasabinas

My own heart-

Beats I stop to listen

In the spatter of rain.

Here, the reader as if reads the confession about the author's affairs and how he listen to his own heartbeats. At the same time, a text with 'I' provides the text with a certain nexus, where the reader can locate him/herself, identifying with 'I' and thus raising the autocommunicativity of the poem - it can also be the reader who listens to his/her heart. 'We' in these cases is even more aggressive, as it already includes a position for a reader by itself. It is interesting to note, that while in the collection of Estonian nature poetry one can repeatedly find a construction, where ' $I$ ' is in the function of patient (or witness) to whom the activities of the landscape objects are directed: the sights open to him/her, the winds beat, the flowers smile etc, then in case of haiku we can find only 17 texts with 'I' as a patient. In more than half

10 The quotation is taken from Jaan Kaplinski's answer to my questionnaire about haiku habits in Estonia, and dates 03.03.2002. The questionnaire was sent to major haiku poets in Estonia to explore the background of their haiku writings. 
of the cases, 'I' is the agent, and surprisingly enough, altogether at 60 cases it is in the function of object.

Using pronominal characters in the function of object deserves a special note here. It is evident that in case of texts, which are analysed by Yuri Levin and Mihhail Lotman, i.e. in case the texts are long and explicit enough for creating a model situation, it does not constitute a major difference if at one instance the pronominal character is expressed in another function on the surface level of the text. However, as haiku demands utmost economy of expression, most pronouns occur only once, and the way they are expressed on the surface level of the text acquires considerable importance. For example in Ain Kaalep's haiku

Su kleidi lilli

väldib mesilane, sest

aimab mu kiivust.

The flowers of your dress

The honey-bee avoids, 'cause

It senses my jealousy.

the situation is very clear — "I am jealous of you" - but in the text both 'I' and 'you' are expressed only as possessive attributes, and the agent is the bee. We can observe the similar tendency in a considerable amount of texts (among 'I'-'you' poems even up to 70\%). The activities are performed by other objects connected with 'you' or 'me' and not by ourselves. It is evident that these texts are reducing the communicational force of the otherwise strongly communicational pronouns, and thus we can consider this tendency a means to approach the Japanese model of projecting communication into text. In addition to that, the communicational force can be reduced also by the elliptic use of pronouns, or using short pronominal forms instead of the longer ones, ${ }^{11}$ or alternating the point of view.

${ }^{11}$ In the Estonian language, a category of person can be expressed in three different ways. The personal pronouns have two different forms, the longer and the shorter one, which can alternate freely, the main argument towards the use of the longer form being stress (e.g., 'mina teeksin', 'ma teeksin' = 'I would make'). Person can also be expressed only by verb endings ('teeksin' = 'I would make'). It is clear, that as the stress laid on the subject is different in all three cases, the communicational impact of the poem is also different. In an unpublished study conducted in 1998, I found that in spoken Estonian the elliptic use of pronouns (the pronouns are omitted in the sentences where their use is grammatically correct) makes up roughly about $1 / 4$ of all the occurrences analysed. For example 


\section{The texts with a free actantial position}

As Umberto Eco indicates, the author as a textual strategy may be expressed in a text by an actantial role (Eco 1984: 10), which means that it does not necessarily take a pronoun for the author to make $\mathrm{him} /$ herself manifest in the text. Therefore, the fact that there are no pronouns in the text, does not make this poem void of communication a priori, as proposed by the theories of Yuri Levin and Mihhail Lotman. Of course, again the problem might not arise with the kind of texts they analyse — the romanticist and symbolist poetry —, but considering the brevity of haiku poems, it is evident that not all the actantial roles might be expressed explicitly. Depending on a poem, this gap in the information about the model situation can become an active trigger mechanism in the communicative situation.

For example in the haiku by Juhan Viiding,

Jaapan on kaugel

eesti on kaugemal veel

ütlevad tuuled

Japan is far

Estonia is even further -

The winds say,

for the winds to say something, there must be someone to say it to, but this someone is not deducible from the text. The author here has created an empty position in the model of the text, in this instance, the receiver of the message sent by the winds. The reader can easily place him/herself in the middle of the model situation, whereas in case of objective texts the only possible position for the reader would be that of the witness outside the situation.

Such texts are altogether $93(6.4 \%)$ and most of them (59) are connected with the verbs of perception, directional verbs (verbs of motion, but also 'smile', 'say to' etc), and reflexive verb forms; there are also many verses featuring a part of human body ('arm', 'forehead' etc 20) and spatial relations ('further', 'closer', 'up' 'down' etc -14 texts).

Failing to mention the character explicitly enhances autocommunicational processes in the reader, as s/he, when forced to supplement

in the haiku texts with 'I' the elliptical use of pronouns (subject is expressed only by verb endings; the cases with implicit subject cannot be included here) makes up $66 \%$. 
the missing character and interpreting this position usually as an 'I'character, has to remodel $\mathrm{him} / \mathrm{h}$ erself according to the situation. Textual activity passes on from the writer to the reader.

Similar reading pattern is common also to Japanese haiku, especially because the Japanese language does not indicate the subject if it is deducible from the context. Therefore, often the most logical reading is to interpret the text through ' $I$ ', although the text does not contradict the other patterns. For example in Bashō's

(755) 瓶わる〉夜の水のねざめ哉

kame waruru yoru no kōri no nezame kana ${ }^{12}$

The jar crackles/ that icy night/ when waking up

the typical reading would be to say that 'I' wake up, and not somebody else.

\section{Texts with rhetorical questions and apostrophes}

Another type of texts in the transition zone between the explicitly communicative texts of haiku and the so-called "catalogues of landscape" are the texts, where the picture of landscape is accompanied by or given through a rhetorical question (51) or an apostrophe (37). These questions and exclamations have no addressee, thus they tend to trigger the autocommunicative activity both on the part of the reader and the author. The questions either contain an answer or are not meant to be answered at all.

For example in Aime Piirsalu's haiku

Kumb kumma kaissu

tormavad meri või maa

Jäämineku aeg

Who rushes to embrace whom

The sea or the land

The time of breaking up the ice,

the author gives us a picture of ice, which is melting on the sea and is washed ashore by the waves. The role of the question here is to

12 The Japanese haiku texts are taken from the Bashō poetry volume of Nihon koten bungaku taikei (Bashō 1974). The number in front of the text signifies the number of the text in this edition. All translations are mine (K. L.). 
strengthen the image by stimulating the autocommunicative activity in the poem.

The communicational force of the apostrophe is even lower than that of the rhetorical question, because in the former, the author does not even create a fictitious dialogue. In any case, also in these texts the author's position and his attitude to the object are defined, and thereby the readers are provided with a position inside the model situation of the poem. Thus we can say that even though these texts are less intense in their communicative potential than the texts with pronouns, the landscapes here are still openly communicational.

\section{"Philosophical" texts}

A border case between the openly communicational texts and the objective texts on one hand and the catalogues of landscape on the other, are so-to-say "philosophical" texts, which resemble epigrams and are relatively didactic. They contain aphorisms or maxims, sometimes witticisms based on word-play. Although these texts do not contain communicational devices discussed above, they are by no means objective, because the author's presence is most manifest. The author presents his/her assertion and what is left to the reader is to agree or disagree. Most of the 124 texts here are written by amateurs, but a special group is formed by surrealistic haiku texts.

\section{Objective texts}

As it was mentioned above, Mihhail Lotman considers a text objective or void of communication, if there are different characters in the model situation constructed after the text, but the text itself is written in the third person (M. Lotman 1989). And indeed, there is a considerable amount of Estonian haiku, which do not contradict this approach. These are texts, which usually consist of one sentence or at least maintain the same agent all through the poem. We must note here, that this agent is not designated by a pronoun in the text, therefore the author's point of view is not manifest. Of course, the choice of words and the use of imagery always tell us something about the author's preferences, so the objectiveness here is strictly the lack of communicative activity in the model situation of the text and nothing else. 
For example Ly Seppel's haiku

Hall varblaseklutt

ei mõelnudki lahkuda

paljaks jäänud oksalt

Grey sparrow urchin

Didn't even think of leaving

The branch grown bare

can be called objective in this sense, because here we are offered a description of the actions of somebody else (the sparrow), without a smallest possibility to place ourselves into the situation described. Objective texts are altogether 63 (4.3\%).

\section{Catalogues of landscape}

The biggest amount of Estonian haiku texts (713), however, do not belong to any of the types analysed above. They do not contain pronouns, do not contain rhetorical figures like rhetorical question and apostrophe; they refuse the reader any kind of place inside the model situation, yet they do not belong among the objective texts, because there is no line of narration. These texts consist of naming a number of landscape objects, and the model meaning of the text is a picture or a concept, like "spring morning", "passing of time", "like in Japan", etc. None of the theories mentioned so far (Levin, Lotman, Eco, Foucault) would find communication or indices of authorial function in these texts. Can we say that these texts are finally the ones void of communication? Is there a communication in a piece of landscape?

In the analysis of those texts there surges the question of personification in one-syntagma verses. On one hand, the a text like Venda Sõelsepp's

Kraavid kannavad

rõõmsalt lauldes õlgadel

hangede laipu

The ditches carry

On their shoulders, merrily singing,

The corpses of [snow]drifts

clearly depicts a picture of a quick-flowing water in a ditch, full of snow patches, which float down the current. On the other hand, this is 
written exactly in a form of a description of a situation (and not in some other way), where the agent (ditch), albeit fictitious, performs a certain action (carrying and singing), and therefore it could be classified as objective text. ${ }^{13}$ However, this is not the approach taken here, especially in the light of the text group yet to be analysed below. The fact, that a landscape object is given through a strong personification imposes authorial interpretation more than it would be in case of mere naming, and the construction in general betrays strong influence of Western poetic patterns, but still we can find the similarities with the rest of the catalogues of landscape in their functioning: they search to endow the landscape with its own communicational force.

One of the main requirements of Bashō-style haiku is its dyadic structure, even the most important in the opinion of many of his students (Shirane 1998). This has been taken the main principle of haiku's poetics also by many modern scholars (e.g., Kawamoto 2000). A haiku must consist of at least two independent parts, which are separated by a cutting word or kireji. Bashō is recorded to have said the following:
發句の事は、行きて歸る心の味也。たとえば「山里は萬歳遲し梅の花 」といふ類也。「山里は萬歳おそし」とい〉はなして、梅は咲りといふ 心のごとくに、行きてかへるの心發句也。[ [...] 先師も「發句はとり合物と知るべし」と言るよし、[... ] 。
Hokku feels like a heart that goes and returns. For example: "Mountain hamlet/ manzai dancers are late/ plum blossoms". Having said "mountain hamlet, late manzai dancers" and then going to the blooming plums - that's what is a haiku with a mind that goes and returns. [...] The teacher said as well: "Know, that a hokku is combining things [...]." (Bashō 1966: 211)

This means that a classical Japanese haiku must inevitably comprise at least two different points of view, and can not maintain the same agent through the poem, like the last kind of Estonian texts analysed above. By focusing in one verse equally to big and small, eternal and transient, or just juxtaposing two things from totally different spheres of existence, the author is supposed to give a picture of the whole universe. Using too similar entities is considered to be of bad taste. Haruo Shirane compares a dyadic haiku to ikebana, saying that similarly to a flower arrangement artist, who "“"cuts" the flower, opening up space that the audience can enter into with his or her imagination" (Shirane 1998: 83), the cutting word in haiku "opens up a space that

${ }^{13}$ When a text consist of two syntagmas, i.e. describes the actions of two independent fictitious characters (landscape objects), the question does not arise, because there is no possibility to reduce such a verse to one model situation. 
the haikai reader occupies metonymically or synecdochically, by moving from a detail or part to an imagined whole, filling out the scene or narrative [...]" ${ }^{\prime 14}$ (Shirane 1998). Makoto Ueda argues that that the cutting word is the key to haiku's impersonality, as by cutting the verse all personal emotions and feelings in it will turn into universal and thereby impersonal by themselves (Ueda 1991: 1555).

Avoiding overt emotion and personal feelings is essential to haiku, as it is exemplified by many passages in Bashō's teachings. Konishi Jin'ichi claims that if a waka poet wrote about the darkening sea and a duck, s/he definitely added a comment on how it feels: sad, nostalgic, funny etc (choosing from among the emotions permitted in the item's poetic essence, of course). But Bashō, turning away from this tradition, wrote simply

(801)海くれて鴨のこ总はほのかに白し

Umi kuretel kamo no koe hal honokani shiroshi

The sea darkens/ A wild duck's call/ Is vaguely white. (Konishi 1999: 84-85)

Zen-influenced haiku criticism (e.g., Blyth 1978; Yasuda 1995; but also Konishi 1999, and others) considers haiku to be an expression of satori, it is, an expression of intuitive insight into the true nature of things and phenomena, it is a spiritual fusion with the surrounding world, which demands absolute egolessness from the author. In order to write, the author must give up his impressions and prejudices and dissolve into its subject matter.

The largest amount of texts, altogether 456, among Estonian haiku can be regarded as this kind of descriptive catalogues of landscape objects. Estonian haiku, having developed in the cross-influence of European literary conventions and ambiguous laconism of Japanese haiku, obviously do not conform uniformly to these Japanese rules, which demand the absolute disappearance of the author from the scene. In many cases the extensive use of rhetorical figures leaves no space for the reader's interpretative activity, limiting the possible range of meanings to minimum. Also we can see that the landscape, which the verses depict, is different with Bashō and Estonian authors. According to Karatani Kōjin, Alan Watts and others, Bashō's poetry and Zen poetry in general is by no means representative. Rather it tends to depict an ideal, conceptualised nature, it is, the landscape as

${ }^{14}$ In the same book, he likens the mechanism to a film montage, where a close shot can be followed by a long shot etc, where the different parts can be related like in a metaphoric or a metonymic montage in Eisenstein's fashion (Shirane 1998: 98f). 
such. (Karatani 1993; Watts 1990) At the same time Estonian haiku prefers to describe a real landscape and the real objects in a given moment.

However, these differences do not change the way these catalogues of landscape work in regards to their communicative activity. The author gives us only pieces of landscape, which the reader has to put together into a picture, moving from one object to another. Unlike in Japanese literature, a haiku here can also comprise more than two different points of view, and there are texts, where there exist even up to five different entities. That this is a feature of haiku mentality, and not of nature poetry in general, can be seen from the fact that in the collection of Estonian nature poetry (Vaarandi 1980) there are only 25 poems, which could be labelled a catalogue. Moreover, we can observe the similar tendency to combine multitude of objects, i.e. to present a catalogue, also among the texts which contain communicational elements and were analysed above: 327 poems out of 610 alternate the point of view in the course of the poem, giving different aspects of the same situation or giving background and situation separately.

For example, a haiku by Mart Raud:

Pakatab koidik.

Kerge virvendus järvel.

Kuldkalad koevad

The dawn bursts.

Slight ripple on the lake.

The goldfish spawn.

Also a haiku by Jaan Kaplinski:

Esimene jälg

esimesel lumel öö

latern kirsipuu

The first print

On the first snow night

A lantern a cherry-tree.

Sometimes the very topic of the haiku, i.e. the concept of its model meaning, is already mentioned inside the text as one of the entities. 
For example, a haiku by Väino Vesipapp:

Lume soojusest

tedred paiskuvad lendu.

Pakasehommik.

From the warmth of snow

The grouse flush.

The morning of frost.

In this last instance, the reader can feel the author's presence in a more imperative manner than with haiku, where the reader has to decide the topic by him/herself. Nevertheless, this does not change the principal way in which these verses function from the communicative point of view.

In one of his most famous teachings, Bashō has explained how to write a good haiku as following.

松の事は松に習へ、竹の事は竹に習へと師の詞のありしも、私意をは なれよといふ事也。此習へといふ所を己がままにとりて、終に習はざ るなり。習へといふは、物に入つて之の微の顯れて情感ずるや、句亡 成る所也。

Learn [the way of] pine from the pine. [The way of] bamboo - learn from the bamboo. These are teacher's words. It means: move away from your own thoughts. If you do this learning after yourself, you do not learn anything in the end. Learning is to go into the things, to feel the core of their essence, and this becomes a verse. (Bashō 1966: 175)

Principally this teaching means that the author should sacrifice his own self, dive into his object and let it do its own talking.

This is exactly the way the catalogues of landscape function. The author is dead, in the sense that $\mathrm{s} / \mathrm{he}$ has dissolved into several points of view, which in the texts are expressed by different elements of landscape. The pieces of landscape assume the control of the author and the author gives each of them its own personal voice. Thus we can hear the voice of a potato, the voice of a crow, the voice of a falling leaf, all at the same time. Once again we see that a poetic device elevates landscape object to an equal, if not more than equal partner for a human being. In a sense these texts become the ideal triggers of autocommunication, as through multitude of voices and an extreme activity demanded from a reader to fill up the space provided by a cut in the poem, the text becomes a code to remodel the writer's/ reader's self. But is that a communication in other senses, is hard to say. Rather, in the sense that the sum of all the different colours is white, we can say that the sum of all the voices of all the elements of the 
landscape is non-communication, i.e. the noise, which has resided into silence.

\section{Conclusion}

We have seen that Estonian haiku uses different patterns of projecting communication and authorial relations into a poem, deriving both from Estonian literary conventions and the tradition of Japanese haiku. On one hand, Estonian haiku uses communicative elements like personal pronoun, rhetorical questions, addresses and apostrophes and free actantial positions relatively frequently, but on the other hand we have seen that the devices used tend to enhance the autocommunicational activity of the poem, rather than enforcing communicational relations in the manner of Romanticist poetry or also Estonian nature poetry in general. It is also clear that the question of communicativity in a piece of poetry is not a meagre amusement of the scholars of poetics, but carries significant ontological implications. For Estonian haiku, and haiku in general, communicative perspective is one of the most important means to convey its poetic principle: to animate landscape, to impose communicational activity on the elements of nature, to treat nature as an equal for humans and annihilate ego by fusion into landscape objects.

\section{References}

Bashō $1966=$ 「三冊子」『芭蕉全集 - 第七巻・俳論集』東京・角川書店・ 昭和 41，151-236.

Bashō $1974=$ 『芭蕉句集 $\cdot$ 日本古典文学大系45. 』大谷徳蔵 $\cdot$ 中村俊定 (校注)。東京・岩波書店・昭和 49 .

Beichman, Janine 1986. Masaoka Shiki. Tokyo: Kodansha International.

Blyth, Reginald H. 1978. Zen and Zen Classics. New York: Vintage Books.

Eco, Umberto 1984. The Role of the Reader. Bloomington: Indiana University Press.

Foucault, Michel 1989. What is an author? In: Lodge, David (ed.), Modern Criticism and Theory. London: Longman.

Horikiri Minoru 2002 = 堀切実『表現としての俳諧。芭蕉・囬村』東京・ 岩波書店.

Jakobson, Roman 1966. Closing statement: Linguistic and poetics. In: Sebeok, Thomas A. (ed.), Style in Language. Cambridge: MIT Press, 350-377. 
Karatani, Kōjin 1993. Origins of Modern Japanese Literature. Durham: Duke University Press.

Katō, Shūichi 1997. A History of Japanese Literature: From Man'yōshū to Modern Times. Richmond: Japanese Library.

Kawamoto, Kōji 1993. The poetics of short poems: Haiku and imagist poetry. In: Thomas, R. K. (ed.), Poetics of Japanese Literature. Purdue University, 1-12.

- 2000. The Poetics of Japanese Verse: Imagery, Structure, Meter. Tokyo: University of Tokyo Press.

Keene, Donald 1971. Landscapes and Portraits. Tokyo: Kodansha International Ltd.

Konsihi Jin'ichi 1999 = 小西其一『日本文藝の詩学』東京・文すず書房.

Levin, Yuri 1973. = Левин, Ю. И. 1973. Лирика с коммуникативной точки зрения. In: Eng, Jan van der; Grygar, Mojmir (eds.), Structure of Texts and Semiotics of Culture. The Hague: Mouton \& Co, 177-195.

Lindström, Kati 2001. A broad perspective on Estonian haiku as compared to its Japanese origin. Studia Humaniora Tartuensia (2). Available at http:// www.ut.ee/klassik/sht/2001/lindstroem1.pdf

Lobo, Luiza 1995. Haiku in Brazil. In: Kawamoto, K.; Yuan, H.; Ohsawa, Y. (eds.), The Force of Vision, 6: Inter-Asian Comparative Literature. Tokyo: Tokyo University Press, 98-107.

Lotman, Mihhail 1989. = Лотман, М.Ю. К семантической типологии русского стихосложения. In: Зализняк, А. А. (ed.), Славянское и балканское языкознание: Прозодия. Москва: Наука, 76-98.

- 2001. The paradoxes of semiosphere. Sun Yat-sen Journal of Humanities 12 (April): 97-106.

Lotman, Yuri 1990a. The Universe of Mind. London: I. B. Tauris \& Co.

- 1990b. Kultuurisemiootika. Tallinn: Orion.

Lotman, Yuri; Broms, Henri 1988. Greeting to the symposium. An interview with Yuri Lotman in Helsinki, June 1987. In: Broms, Henri; Kaufmann, R. (eds.), Semiotics of Culture. Helsinki: Arator, 115-123.

Raud, Rein 1984. Mõni sõna haikude kohta. Sirp ja Vasar 2 (2058) (13.01.1984): 5.

- 1994. The Role of Poetry in Classical Japanese Literature. Tallinn: Eesti Humanitaarinstituut.

Sakamoto Hyakudai 1989. The Structure of 'the 和-wa' — concept as a semiotic interface characterising Japanese ethos. In: Balat, Michel; Deledalle, Janice (eds.), Signs of Humanity: Proceedings of the IVth International Congress of IASS, Barcelona/Perpignan 1989 (vol. 3). Berlin: Mouton de Gruyter, 1561-1564.

Shirane, Haruo 1998. Traces of Dreams: Landscape, Cultural Memory and the Poetry of Bashō. Stanford: Stanford University Press.

Vaarandi, Debora (ed.) 1980. Eesti looduslüürikat. Tallinn: Eesti Raamat.

Ueda, Makoto 1991 [1967]. Impersonality in Japanese poetry: Bashō on the art of haiku. Ueda, Makoto (ed.), Literary and Art Theories in Japan. (Michigan Classics in Japanese Studies 6.) Ann Arbour: The University of Michigan Press, 145-172.

Watts, Alan W. 1990. The Way of Zen. Arkana: Penguin Books.

Yasuda, Kenneth 1995 [1957]. The Japanese Haiku. Rutland: Charles E. Tuttle Company. 


\section{Автор, пейзаж и коммуникация в эстонском хокку}

В статье предпринимается попьтка найти ответ на вопрос, каким образом в эстонском хокку моделируется образ автора и осуществляется коммуникация с читателем. Автор полагает, что хотя эстоноязычные хокку очевидно носят следы влияния западной литературной традиции и авторская позиция в них отмечается с помощью различных коммуникативных стратегий (личные местоимения, риторические обращения, вопросы и восклицания, свободные актантные позиции), - тем не менее, большинство текстов опирается все же на японскую литературную модель. Такие тексты, как «каталоги пейзажей» представляют читателю ряд объектов пейзажа, не развивая при этом линию рассказа. Каждому элементу пейзажа дается свой «голос», и посредством разнообразия таких голосов читателя вынуждают вступить в автокоммуникативный процесс моделирования себя.

\section{Autor, maastik ja kommunikatsioon eesti haikus}

Artikkel üritab leida vastust küsimusele, kuidas eesti haikukirjandus modelleerib autori kuju ja kommunikeerub lugejaga. Autor leiab, et ehkki suur osa eesti haikudest on kantud ilmselgelt lääne kirjandustraditsiooni mõjudest ja märgib autori positsiooni erinevate kommunikatiivsete strateegiate abil (personaalpronoomenid, retoorilised pöördumised, küsimused ja hüüatused, vabad aktantilised positsioonid), siis enamus tekstidest on siiski selge jaapani kirjandusmudeli mõjuga. Sellised tekstid, nn "maastikukataloogid" esitavad lugejale rea maastikuobjekte, jutustusliini arendamata. Igale maastikuelemendile on seeläbi antud oma "hääl" ning sellise häälte mitmekesisuse kaudu sunnitakse lugejat astuma autokommunikatiivsesse enesemodelleerimise protsessi. 